\title{
Sosyal Yardımlaşma ve Dayanışma Vakfı Eğitim Yardımlarının İlkokul, Ortaokul, Lise Öğrencileri ve Ailelerine Etkileri (Antalya İli Muratpaşa İlçesi Örneği)
}

\author{
The Effects of Social Foundation Aids on Elementary, Middle School And High \\ School Students and Their Families \\ (A Sample from Muratpasa District, Antalya)
}

\section{Cemali SARI ${ }^{*}$ Nurettin ERDOĞAN**}

\begin{abstract}
Öz: Bu çalışmanın amacı Sosyal Yardımlaşma ve Dayanışma Vakıfları (SYDV) tarafından gerçekleştirilen eğitim yardımlardan faydalanan aileler ve öğrencileri üzerindeki etkilerini belirlemek ve olası sorunlara yönelik çözüm önerileri ortaya koymaktır. Veri toplama aracı olarak anket kullanılmış olup araştırmanın evrenini Antalya İli Muratpaşa İlçesi SYDV'ndan eğitim yardımı alan aileler oluşturmuştur. Araştırmanın örneklemi tesadüfi atama yöntemiyle belirlenmiştir. Elde edilen veriler, SPSS 21.0 (Statistical Program for Social Sciences) istatistik programı yardımıyla frekans, yüzde analizi ve betimleme yöntemi kullanılarak incelenmiştir. Yardımlardan faydalanan ailelerin eğitim düzeylerinin düşük olduğu, ailelerin öğrencilerinin eğitim ihtiyaçlarını karşılamakta çok zorlandıkları, nakdi olarak verilen eğitim yardımlarının büyük bir bölümünün amacına uygun kullanılmadığı, öğrencilerin okula devam durumunu önemli oranda etkilediği ortaya çıkmıştır.
\end{abstract}

Anahtar Sözcükler: Eğitim Yardımları, Öğrenciler ve Aileleri, Antalya

Abstract: The aim of this study was to determine effects of the education aids provided by the Social Assistance and Solidarity Foundations on students and their parents, as well as providing solutions to the problems through gathering the opinions of those families who are supported with educational aids. The data employed in this study was gathered through a questionnaire with the volunteer participants and questionnaire forms which were developed by the researcher were employed as the data gathering instrument. The sample population were selected through the random sampling technique, from amongst those families who received educational aids from the Ministry of Family and Social Policies, in the Muratpasa district of Antalya. The collected data was analyzed by means of a Statistical Program (SPSS 21.0) and reported as frequencies and percentages and the findings were discussed descriptively. The finds also revealed that the majority of the families were low-income families and they had difficulty in meeting the educational requirements of their children.

Keywords: Education Aids, Students and Their Families, Antalya

\footnotetext{
*Akdeniz Üniversitesi Edebiyat Fakültesi Coğrafya Bölümü, Doç. Dr., Antalya. cemsari@yahoo.com.

** Muratpaşa Sosyal Yardımlaşma ve Dayanışma Vakfı Müdürlüğü, Antalya.
} 


\section{Giriş}

Yoksulluk pek çok farklı boyuta sahip sosyal bir meseledir. Gelir yoksulluğu ve insani yoksulluk iki önemli boyutunu oluşturmaktadır. Gelir yoksulluğu, insanın temel ihtiyaçlarını karşılamak için gerekli gelirin eksikliği olarak tanımlanabilir. İnsani yoksulluk ise kötü yaşam beklentisi, kötü anne sağlığı, cehalet, yetersiz beslenme düzeyi, güvenli içme suyuna erişimin olmayışı gibi beşeri yeteneklerinin eksikliği olarak tanımlanabilir (UNDP 2003). Ancak ekonomik kaynakların eksikliği yoksulluğun tek belirleyicisi değildir. Konunun toplumsal bağlamı da göz önüne alınmalıdır. Bu bağlamda, yoksulluk tanımı kişinin içinde yaşadığı topluma katılma kapasitesi açısından değerlendirilmektedir (Atkinson \& Marlier 2010).

Dünya çapında son yıllarda birçok ülkede farklı kapsamlarda ve farklı bütçelerle uygulanmakta olan eğitim yardımı programları yoksulluğu azaltmada kullanılan sosyal yardım politikası uygulamaları arasında önemli bir yer tutmaktadır. Eğitim yardımları, diğer yardımlardan farklı olarak yardım alan kişilerin eğitim hizmetlerine katılımları şartıyla ödemelerin devam ettirildiği şartlı bir yardım programıdır. Ödemelerin devam etmesi için uyulması gereken bu şartlarla özellikle yoksul ailelerin çocuklarının beşeri sermayelerine katkıda bulunulmakta ve ekonomik şoklar karşısında stratejiler geliştirebilecek yeterliliğe sahip olmalarına katkıda bulunulmaktadır. Eğitim yardımları bu özelliği ile kronik yoksulluk içerisinde yaşayan ve yoksulluğu gelecek kuşaklara miras olarak bırakan kişi ya da gruplar üzerinde hem kısa hem de uzun vadeli etkilere sahip olmaktadır (Esenyel 2009).

Türkiye'de eğitim yardımları 1986 yılında kurulan Sosyal Yardımlaşma ve Dayanışma Vakıfları (SYDV) aracılığıyla yapılmaya başlanmıştır. Daha sonra teknolojinin gelişmesiyle birlikte daha sistemli hale getirilmiştir. Özellikle 2009 yılında Sosyal Yardımlar Genel Müdürlüğü (SYGM) tarafindan kurulan ve SYDV'ler tarafından kullanılmaya başlanan SOYBISS (Sosyal Yardım Bilgi Sistemi) sayesinde daha sistemli ve hızlı hizmet vermeye başlamışlardır.

Türkiye'de 2001 yılında Dünya Bankası tarafindan mali olarak desteklenen Sosyal Riski Azaltma Projesi (SRAP) başlatılmıştır. SRAP ekonomik krizin yoksul haneler üzerindeki etkilerini hafifletmek, mevcut sosyal güvenlik ağ programlarını genişletmek ve güçlendirmek amacyyla uygulamaya konulmuştur. Bu hedeflere ulaşmak için SRAP çerçevesinde Şartlı Nakit Transferi Programı (ŞNT) başlatılmıştır. ŞNT yoksulların eğitim ve sağlık hizmetlerine olan talebini teşvik etmek için, olumlu davranış değişikliği şartına bağlı olarak ailelere sürekli para yardımları sağlar. ŞNT programlarının önemli özellikleri olan çocuklu ailelerin hedeflenmesi ve para yardımlarının kadınlara yapılması, kadınların sosyal hayata katılımlarını artırmaya yönelik çabalara katkıda bulunur. Daha sonra bu eğitim yardımı programının adı Şartı Eğitim Yardımı (ŞEY) şeklinde değiştirilmiştir. Eğitim programının bir diğer hedefi ise okul terklerinin azalmasina katkıda bulunmaktır (Aile ve Sosyal Politikalar Bakanlığ 2012).

ŞEY programı Türkiye çapında her il ve ilçede faaliyet gösteren Sosyal Yardımlaşma ve Dayanışma Vakıfları (SYDV) tarafından aktif olarak uygulanmaktadır (Aile ve Sosyal Politikalar Bakanlığ 12014). SYDV'ler 2012 yılında kullanılmaya başlanan Bütünleşik Sosyal Yardım Sistemi sayesinde $S B E Y$ yardım programını kolay bir şekilde uygulamaktadırlar. Bu sistem sayesinde öğrencilerin devam durumları e-okul sistemine girilmesiyle aynı anda ekranda görülebilmekte ve devam takipleri de kolayca yapılabilmektedir.

Yoksulluğun bir kader olmadığı ve babadan oğula geçen bir miras da olmadığ1 fikrinden hareketle yoksulluğun azaltılmasında eğitimin çok önemli bir yeri bulunmaktadır. Özellikle dezavantajlı ve yoksul kesimler bütün ülkelerin risk grubunda bulunmaktadırlar. Özellikle parçalanmış ailelerin çocukları, kalabalık aileler, yeterli ve düzenli gelire sahip olmayan aileler 
risk grubu içerisindedirler. Toplumsal riski azaltmanın en etkili yollarından birisi de risk altındaki bireylerin eğitimlerinin sağlanması olarak değerlendirilebilir.

Yoksul aileler çocuklarının eğitim ihtiyaçlarını ve kendi ihtiyaçlarını karşılamakta zorlandıklarından, eğitim çağındaki çocukları okuldan alıp çalıştırmak zorunda kalmaktadırlar. Bu da ülke için büyük bir sorun oluşturmaktadır.

Muratpaşa Sosyal Yardımlaşma Vakfi Türkiye ve dünya genelinde uygulanan eğitim yardımlarından farklı olarak şartlı eğitim yardımı yanında, eğitim öğretim yılı başlarında öğrencilerin ihtiyaçlarının bir kısmını ayni, bir kısmını ise nakdi olarak karşılamaktadır. Bu yardımlar kırtasiye ihtiyaçları, okul formaları, çanta, ayakkabı ve okulu evinden uzakta olan öğrenciler için öğrenci taşıma yardımlarıdır.

Bu çalışmada Muratpaşa Sosyal Yardımlaşma ve Dayanışma Vakfı'nın yaptığı eğitim yardımlarının ilkokul, ortaokul ve lise öğrencileri ve ailelerine etkileri ortaya konulmaya çalışılmıştır.

\section{Araștırmanın Amacı ve Önemi}

Bu çalışmanın amacı Muratpaşa Sosyal Yardımlaşma ve Dayanışma Vakfı'nın yapmış olduğu eğitim yardımlarının, fayda sahibi aileler ve öğrencileri üzerindeki etkilerini araştırmaktır.

$\mathrm{Bu}$ amacı gerçekleştirmek şu sorulara yanıt aranmıştır.

- Sosyal Yardımlaşma ve Dayanışma Vakfi tarafından sağlanan eğitim yardımlarının, yardım alan ailelere göre ilkokul, ortaokul ve lise öğrencilerinin okula devamsızlıkları üzerindeki etkisi nasıldır?

- Sosyal Yardımlaşma ve Dayanışma Vakıfları tarafından yapılan eğitim yardımlarının, yardım alan ilkokul, ortaokul ve lise öğrencilerinin aileleri üzerindeki etkileri nelerdir?

- Eğitim yardımları amacına uygun kullanılmakta mıdır?

- Eğitim yardımlarının anneye verilmesi ev hanımı annelerin hanedeki sosyal konumunu nasil etkilemektedir?

- Yardımların etkinliği ve izlenebilirlikleri açısından değerlendirmeler nelerdir?

- Muratpaşa SYDV'nin eğitim yardımları yeterli midir?

- Fayda sahibi vatandaşlar daha farklı hangi eğitim yardımlarına ihtiyaç duymaktadir?

- $\mathrm{Bu}$ çalışmada eğitim yardımlarının yardımlardan faydalanan ailelerin yaşamları üzerinde meydana getirdiği ve getirebileceği değişiklikleri ortaya koyması bakımından önemlidir.

\section{Araştırmanın Yöntemi ve Metodu}

$\mathrm{Bu}$ çalışma betimsel tarama modeline uygun olarak tasarlanmıştır. Çünkü tarama modelleri geçmişte ya da halen var olan bir durumu var olduğu şekli ile betimlemeyi amaç edinen araştırmalar için uygun bir modeldir (Karasar 2006).

Araştırmanın ulaşılabilir evrenini Muratpaşa Sosyal Yardımlaşma ve Dayanışma Vakfı'ndan eğitim yardımı alan aileler oluşturmaktadır. Bu bağlamda araştırmada rastgele (Random) örnekleme tekniği kullanılmıştır. Bu örnekleme tekniği kolay bulunabilir, kolay ulaşılabilir ve gönüllülük esasına göre araştırmaya katılmak isteyen kişiler üzerinde uygulanan bir örnekleme tekniğidir (Yıldırım \& Şimşek 2011). Evrende 622 aile yer alırken 100 aile örnekleme alınmıştır. 
Çalışmada kullanıcılar tarafindan geliştirilen 27 maddelik anket kullanılmıştır. Daha sonra Sosyal Yardımlardan faydalanan velilerin aldıkları eğitim yardımı hizmetleriyle alakalı memnuniyet formu oluşturulmuştur. Burada fayda sahiplerinin aldığ 1 eğitim hizmetlerinin sunuluş şekli ve karşılaşabilecekleri sorunlar dikkate alınmıştır. Anket soruları belirlenirken verilen hizmette bulunması gereken bazı temel standartlar göz önünde bulundurulmuştur.

Anketler 2015-2016 eğitim yardımları döneminde toplanmıştır. Ankete katılanlara anlaşılamayan maddelerle ilgili gerekli açıklama araştırmacı tarafından yapılmıştır. Anket uygulaması öncesinde araştırmanın amacı araştırmacı tarafindan net bir şekilde açıklanmış ve araştırmaya katılmanın gönüllülük esasına dayandığı ifade edilmiştir. Uygulama süresi yaklaşık 40 dakika sürmüştür.

Verilerin daha kolay analiz edilebilmesi için SPSS veri seti oluşturulmuş ve elde edilen veriler bu veri setine girilmiştir. Verilerin analizinde SPSS $21.0 \mathrm{v}$. kullanılmıştır. Verilerin analizinde betimsel analiz tekniği uygulanmıştır. Çalışmada elde edilen veriler, kullanıcı tarafından geliştirilen 27 maddelik anket formuyla sınırlıdır.

\section{Ĕgitim Yardımları}

Şartlı Nakit Transferi (ŞNT) gibi yardım programları aracılı̆̆ıyla yoksul gruplar temel eğitim ve sağlık hizmetleri alanında desteklenerek ekonomik güçlükler içerisinde olan çocukların üretken birer birey haline gelmeleri sağlanmaya çalışılmaktadır.

Şartlılık ilkesi ile yoksul ailelerin çocuklarına yatırım yapması ve bu yatırımın kalıcı olması sağlanmaktadır. Okul masraflarını ve çocukların çalıştıklarında aileye yapacakları katkıyı da karşılayabilecek kadar belirlenen yardım miktarları ile çocukların temel hizmetlerden faydalandırılmaları sağlanmakta ve nitelikli birer birey olarak ülke ekonomisine katkıda bulunmaları teşvik edilmektedir. Ailelerin şartlılık ilkesini yerine getirip getirmedikleri kontrol edilmekte ve şartlar yerine getirilmediğinde verilen yardım parası kesilerek ailelerde olumlu bir davranış değişikliği meydana getirilmeye çalışılmaktadır.

Eğitime devam şartındaki ana amaç yoksul ailelerin çocuklarını \%80-\%85 devamlılıkla okula göndermelerini sağlamaktır (Rawlings \& Bénédicte 2006). Bu amacı gerçekleştirebilmek için ailelere öğrenci başına yardımlar yapılmakta ve bu yardımlar çocukların okul devamlılı̆̆ şartına bağlanmaktadır. Çocukların okula istenen sıklıkta gidip gitmediği yereldeki uygulayıcılar ve okullar tarafindan kontrol edilmekte ve yardımlar ailelere şartları yerine getirdikçe yapılmaktadır. Uygulanmaya başlanan e-okul sistemiyle devamsızlıklar otomatik olarak sistemden takip edilebilmektedir. Son yıllarda verilen yardımların miktarları okula gidiş-gelişlerde ve kırtasiye malzemeleri alımı sırasında harcanan paraları karşılamak ve yaşanan ekonomik şoklar karşısında çocukların çalışmak zorunda bırakılmamalarını sağlayabilmek için karşıt maliyetleri de içerecek şekilde hesaplanmaktadır. Ailelerin çocuklarını okula göndermelerini daha etkin ve kalıcı bir şekilde gerçekleştirebilmek ve özellikle yoksul kesimlerde sıkça rastlanan kız çocukların okul terklerini engelleyebilmek amacıyla ŞNT kapsamında yapılan ödemeler çocukların devam ettikleri sınıfa ya da cinsiyetine göre de değişiklik göstermektedir. Bu kapsamda ailelere ödenen paralar genelde okula devam eden kız çocukları ve ortaöğretim öğrencileri için daha fazla miktarlarda olmaktadır.

Türkiye'de uygulanmakta olan ŞNT yardım programı Dünya Bankası ve Türkiye Cumhuriyeti Hükümeti arasında 14 Eylül 2001 tarihinde imzalanan ve 28 Kasım 2001 tarihinde yürürlüğe giren bir anlaşma ile uygulamaya konulmuştur. İmzalanan bu anlaşma kapsamında Dünya Bankası'ndan Sosyal Yardımlaşma ve Dayanışmayı Teşvik Fonu'na (SYDTF) 500 milyon ABD Doları kredi ve 134 milyon ABD Doları Türkiye Cumhuriyeti Hükümeti katkısı olmak üzere 
toplamda 634 Milyon ABD doları kaynak tahsis edilmiştir. İmzalanan bu anlaşma Dünya Bankası kredisi kaynaklı bir sosyal gelişim projesi olup, Sosyal Riski Azaltma Projesi (SRAP) şeklinde bir isimle adlandırılmıştır. Kasım 2001 tarihi itibari ile uygulamaya sokulan bu projeyi yürütmek amacıyla SYDTF çatısı altında SRAP Koordinasyon Birimi adı ile bir koordinasyon birimi kurulmuştur. Kredinin kullanımı, proje kapsamında çeşitli yardım programlarının geliştirilmesi, bu programların uygulanması, izleme-değerlendirme faaliyetlerinin yürütülmesi ve Dünya Bankası'na programın genel gidişatı ile ilgili gelişmelerin düzenli olarak raporlanması gibi işlemler SYDTF çatısı altında SRAP koordinasyon birimi tarafından yürütülmüsşür.

Şartlı Nakit Transferleri bileşeni kapsamında ise nüfusun en yoksul \%6'l1k dilimine giren kişilere yönelik şartlı bir yardım programı olarak hayata geçirilmiştir. Amacı kısa vadede ekonomik krizin etkilerini etkin bir şekilde en aza indirmek olan bu program uzun vadede ise eğitim ve sağlık alanında verilen şartlı yardım destekleriyle yoksulluğun kuşaklararası transferini önlemeyi amaçlamaktadır.

Dünya Bankası'ndan alınan kredi ile yürütülmekte olan bu programlar 31 Mart 2007 tarihine kadar SRAP Koordinasyon Birimi tarafindan yürütülmüş, bu tarihten sonra ise bütün iş ve işlemleri ile birlikte Sosyal Yardımlar Genel Müdürlügüne (SYDGM) devredilmiştir. Yatırım bileşeni kapsamındaki projeler ve ŞNT yardım uygulaması hâlihazırda SYDGM tarafından yürütülmekte ve finansmanı da SYDTF tarafından karşılanmaktadır (Esenyel 2009).

Türkiye'deki ŞNT'nin ana hedefi nüfusun en yoksul \%6'lık dilimine giren kişilerin kısa vadede maddi desteklerle gelirlerini arttırmak, uzun vadede ise temel eğitim ve sağlik hizmetlerine ulaşmalarını sağlayarak ekonomik şoklara karşı daha dirençli hale gelmelerine yardımcı olmaktır (SYDGM 2007). ŞNT eğitim yardımları, maddi olanaksızlıklardan ötürü 6-17 yaş arasındaki çocuklarını okula gönderemeyen ya da okuldan almak zorunda kalan ailelere çocuklarını düzenli olarak okula göndermeleri şartıyla yapılan yardımları kapsamaktadır. Yardımların tamamı nakdi olarak anneye, eğer anne vefat etmiş ya da çocukların velayetleri babaya verilmişse yardımlar babaya da yapılabilmektedir (SYGM 2007).

ŞNT sisteminde başvuruyu kim yapmış olursa olsun şartlar yerine getirildikçe ödemeler (eğitim süresince her iki ayda bir verilen para, halk arasında, "Öğrenci Parası" ya da "Çocuk Parası" olarak bilinir) annelerin hesaplarına yatırılmaktadır. Böylelikle Türkiye'de en yoksul \%6'lık kesime giren ailelerdeki kadınların en azından ödeme dönemlerinde paralarını almak üzere il ya da ilçe merkezlerine gitmeleri sağlanarak sosyalleşmeleri, verilen para ile de ekonomik güçleri desteklenerek aile içerisindeki statülerinin güçlendirilmesine yönelik dolaylı olarak katkıda bulunulmaya çalışılmaktadır. Ödemelerin annelere yapılması ile ayrıca yardım paralarının aile içerisinde öncelikli olarak çocukların temel ihtiyaçları için harcanması garanti altına alınmaya çalışılmaktadır.

\section{Bulgular}

\section{Katılımcıların Cinsiyetine İlişkin Bulgular}

Yapılan araştırmada eğitim yardımından faydalanan ailelerin demografik analizleri yapılımıştır. Analizler neticesinde Muratpaşa İlçesi'nde eğitim yardımı alan 622 aileden 100 aileye anket uygulanmıştır. 
Tablo 1. Katılımcıların Cinsiyet Dağılımları

\begin{tabular}{lll}
\hline Cinsiyet & $\boldsymbol{f}$ & $\%$ \\
\hline Kadın & 88 & 88 \\
Erkek & 12 & 12 \\
\hline Toplam & 100 & 100 \\
\hline
\end{tabular}

Ankete katılmayı kabul eden öğrenci velilerinden 88'i bayan 12'si ise erkektir.

Katılımcıların Öğrenim Durumlarına İlişkin Bulgular

Tablo 2. Katılımcıların Öğrenim Durumları

\begin{tabular}{lll}
\hline $\begin{array}{l}\text { Öğrenim } \\
\text { Durumu }\end{array}$ & $\boldsymbol{f}$ & $\boldsymbol{\%}$ \\
\hline $\begin{array}{l}\text { Okur-yazar } \\
\text { değil }\end{array}$ & 23 & 23 \\
Okur-yazar & 11 & 11 \\
Illköğretim & 56 & 56 \\
$\begin{array}{l}\text { Lise ve } \\
\text { Üzeri }\end{array}$ & 10 & 10 \\
\hline Toplam & 100 & 100 \\
\hline
\end{tabular}

Fayda sahiplerinin \%23'ünün okur- yazar olmadığı, \%11'nin sadece okuma yazma bildiği, \%56'sının ilköğretim mezunu, \%9'unun lise mezunu olduğu ve sadece bir kişinin üniversite mezunu olduğu belirlenmiştir. Üniversite mezunu olan kişinin aslen yabacı uyruklu ve eşinin vefat ettiği anlaşılmıştır. Bu bulgular bize eğitim seviyesi düştükçe sosyal yardım ve eğitim yardımına olan gereksinimin arttığını göstermektedir. Diğer bir deyişle eğitim seviyesi yükseldikçe sosyal yardımlara duyulan ihtiyaç da azalmaktadır.

\section{Katılımcıların Medeni Durumlarına İlişkin Bulgular}

Tablo 3. Katılımcıların Medeni Durumları

\begin{tabular}{|c|c|c|}
\hline $\begin{array}{l}\text { Medeni } \\
\text { Durum }\end{array}$ & $f$ & $\%$ \\
\hline Evli & 76 & 76 \\
\hline Boşanmış & 19 & 19 \\
\hline $\begin{array}{l}\text { Diğer (Eşi } \\
\text { vefat etmiş, } \\
\text { cezaevinde } \\
\text { vb.) }\end{array}$ & 5 & 5 \\
\hline Toplam & 100 & 100 \\
\hline
\end{tabular}


Görüşülen 100 fayda sahibinden 76'sının evli, 2 kişinin eşinin vefat etmiş, 19 kişinin boşanmış ve 3 kişinin de eşinin cezaevinde hükümlü olduğu tespit edilmiştir.

\section{Katılımcıların Muratpaşa'da Yaşama Nedenine İlişkin Bulgular}

Tablo 4. Katılımcıların Muratpaşa' da Yaşama Nedenleri

\begin{tabular}{lll}
\hline $\begin{array}{l}\text { Muratpaşa' } \\
\text { da yaşama } \\
\text { nedeni }\end{array}$ & $\boldsymbol{f}$ & $\boldsymbol{\%}$ \\
\hline Zorunlu Göç & 5 & 5 \\
İş & 56 & 56 \\
$\begin{array}{l}\text { Ailesinin } \\
\text { buralı olması }\end{array}$ & 28 & 28 \\
$\begin{array}{l}\text { Diğer } \\
\text { sebepler }\end{array}$ & 11 & 11 \\
\hline Toplam & 100 & 100 \\
\hline
\end{tabular}

Tablo 4'de görüldüğü gibi görüşülen 100 fayda sahibinden 5 kişinin zorunlu göç (terör, kan davası, şiddet) sebebiyle Muratpaşa' ya geldiği ve burada yaşadığ 1 , 56'sının iş için, 28 kişinin ailesinin burada yaşadığı için 11 kişinin de diğer (evlilik, merak vs.) sebeplerle Muratpaşa' da yaşadığ 1 anlaşılmıştır. Muratpaşa İlçesi ülkenin en çok göç alan ilçeleri arasında yer almaktadır. 2015 yılı TÜIK verilerine göre yıllık nüfus artış hızı $\% 5$ civarındadır. Bu göçle gelen nüfusun yoksul kesimdeki yansıması da yarıdan fazlasının iş bulabilmek için Muratpaşa'ya geldiği şeklinde açıklanabilir.

\section{Katılımcıların Hanedeki Yaşayan Kişi Sayısına İliş̧in Bulgular}

Tablo 5. Katılımcıların Hane Durumları

\begin{tabular}{lll}
\hline $\begin{array}{l}\text { Hanedeki } \\
\text { kişi sayısı }\end{array}$ & $\boldsymbol{f}$ & $\%$ \\
\hline İki Kişi & 3 & 3 \\
Üç kişi & 10 & 10 \\
Dört Kişi & 22 & 22 \\
$\begin{array}{l}\text { Beş ve } \\
\text { Üzeri Kişi }\end{array}$ & 65 & 65 \\
\hline Toplam & 100 & 100 \\
\hline
\end{tabular}

Yapılan araştırmada 3 ailenin hanede 2 kişi, 10 hanede 3 kişi, 22 hanede 4 kişi, 65 hanede 5 kişi ve daha fazla kişi yaşadığı tespit edilmiştir. Bu durum bize hanede birey sayısı arttıkça yardıma ihtiyaç duyma oranının arttığını göstermektedir. Yaklaşık olarak yardım faydalanıcılarının tamamına yakını kalabalık ailelerden oluşmaktadır. Hanede birey sayısının artması doğal olarak sosyal yardıma olan gereksinimi beraberinde getirmektedir. 


\section{Hanedeki Öğrenci Sayısına İlişkin Bulgular}

Tablo 6. Katılımcıların Hanesindeki Öğrenci Sayısı

\begin{tabular}{lll}
\hline $\begin{array}{l}\text { Hanede } \\
\text { okula } \\
\text { devam } \\
\text { eden }\end{array}$ & $\boldsymbol{f}$ & $\%$ \\
$\begin{array}{l}\text { öğrenci } \\
\text { Bir }\end{array}$ & 24 & \\
İki & 45 & 24 \\
Üç & 18 & 45 \\
$\begin{array}{l}\text { Dört } \\
\text { Üzeri }\end{array}$ & 13 & 18 \\
\hline Toplam & 100 & 13 \\
\hline
\end{tabular}

Fayda sahiplerinin 24'ünün 1 öğrencisi, 45 hanenin 2 öğrencisi, 18 hanenin 3 öğrencisi, 12 hanenin 4 ögrencisi ve sadece 1 hanenin 5 öğrencisi bulunmaktadır. Fayda sahiplerinin yarıya yakınının 2 öğrencisi olduğunu görülmektedir.

\section{Katılımcıların Hanedeki Çalışan Sayısına İlişkin Bulgular}

Tablo 7. Katılımcıların Hanesindeki Çalışan Sayısı

\begin{tabular}{lll}
\hline $\begin{array}{l}\text { Hanedeki } \\
\text { çalışan } \\
\text { sayısı }\end{array}$ & $\boldsymbol{f}$ & $\%$ \\
\hline $\begin{array}{l}\text { Çalışan } \\
\text { Yok }\end{array}$ & 11 & 11 \\
Bir Kişi & 78 & 78 \\
İki Kişi & 10 & 10 \\
Üç ve & 1 & 1 \\
Üzeri Kişi & & 100 \\
\hline Toplam & 100 & \\
\hline
\end{tabular}

Tabloda görüldüğü gibi 11 hanede çalışan kimse bulunmamaktadır. Bu haneler sosyal yardımlarla, komşu, akraba ve tanıdık yardımlarıyla geçinmektedirler. 78 hanede 1 kişi çalışmaktadır. Bunun en önemli sebebi de ailelerin çekirdek aile ve genç aileler olması sebebiyle çalışma yaşında başka kimse bulunmaması ve annelerin büyük bölümünün ev hanımı olmasından kaynaklanmaktadır. Bunun yanında eğitim düzeyinin de düşük olması annelerin iş bulabilme imkânını azaltmaktadır. 10 hanede 2 kişi çalışmakta ve sadece 1 hanede 3 kişi çalışmaktadır. Çalışanların büyük bölümü gündelik işlerde çalışmakta ve düzenli geliri olan hane sayısı çok azdır. Fayda sahiplerinin büyük bir bölümü kayıt dışı ve sabit geliri olmayan işlerde çalışmaktadir. 


\section{Hanedeki Sigara İçen Sayısına İlişkin Bulgular}

Tablo 8. Katılımcıların Hanesindeki Sigara Alışkanlıkları

\begin{tabular}{|c|c|c|}
\hline $\begin{array}{l}\text { Hanede sigara } \\
\text { içen kişi sayısı }\end{array}$ & $f$ & $\%$ \\
\hline $\begin{array}{l}\text { Sigara içen } \\
\text { yok }\end{array}$ & 33 & 33 \\
\hline Bir Kişi & 58 & 58 \\
\hline $\begin{array}{l}\text { İki ve Üzeri } \\
\text { Kişi }\end{array}$ & 9 & 9 \\
\hline Toplam & 100 & 100 \\
\hline
\end{tabular}

Yapılan araştırmada 33 hanede sigara kullanan birey bulunmamakta, 58 hanede 1 kişi sigara kullanmakta, 7 hanede 2 kişi sigara kullanmakta ve 2 hanede ise 3 kişi sigara kullanmaktadır. Ailelere sigara için aylık harcama miktarı ile ilgili sorulan soruda her bir hanenin sigara için yaptığı harcama $100 \mathrm{TL}$ ile $880 \mathrm{TL}$ arasında değişmektedir. Eğitim yardımı alan hanelerden yarıdan fazlasının sigara kullanması nakdi yardımların tamamının olmasa bile bir kısmının amacına uygun kullanılmasını engellemektedir. Yardımların nakdi olarak ödenmesi ve nasıl kullanıldığının denetlenememesi eğitim yardımlarının kötü alışkanlıklar için de kullanılma riskini artırmaktadır. Zaten yetersiz olan hane gelirleri kötü alışkanlıklara da harcama yapıldığından temel ihtiyaçları karşılamaktan bir miktar daha uzaklaşmayı sağlamakta ve yoksulluğun derinleşmesine sebep olabilmektedir. Yine yapılan analizde 4 hanede sigara dişında alkol ve uyuşturucu gibi kötü alışkanlıkların bulunduğu tespit edilmiştir. Hanede bu tür kötü alışkanlıklar olması, bu hanelere nakdi eğitim yardımı yapmanın karar vericiler açısından riskler taşıyacağı düşüncesini artırmaktadır.

\section{Eğitim Yardımlarının Yeterliliğì/Yetersizliği ile İlgili Bulgular}

Tablo 9. Katılımcıların Eğitim Yardımları Hakkında Görüşleri

\begin{tabular}{lll}
\hline $\begin{array}{l}\text { Eğitim } \\
\text { yardımlarını } \\
\text { yeterli } \\
\text { buluyor } \\
\text { musunuz? }\end{array}$ & $f$ & $\%$ \\
\hline Evet & 17 & \\
Hayır & 62 & 17 \\
Kısmen & 21 & 62 \\
\hline Toplam & 100 & 21 \\
\hline
\end{tabular}

Eğitim yardımlarının yeterliliği konusundaki analizimizde ise 17 kişi eğitim yardımlarının yeterli olduğunu, 62 kişi yetersiz olduğunu ve 21 kişi ise kısmen yeterli olduğunu beyan etmiştir. Görüldüğü üzere fayda sahipleri eğitim yardımlarının yetersiz olduğunu düşünüyor ve öğrencilerinin eğitim ihtiyaçlarını karşılamaktan çok uzak olduğunu belirtmektedirler. Yapılan 
anket uygulamasında özellikle $S ̧ E Y$ yardımlarının yetersiz olduğu belirtilmektedir. 2016 yılı için ilk ve ortaokul öğrencilerine (kız öğrenciler için aylık 40 Lira, erkek öğrenciler için aylık 35 Lira) lise öğrencilerine (kız öğrenciler için aylık 60 Lira, erkek öğrenciler için aylık 50 Lira) şeklinde ödenmekte ve ödemeler eğitim süresince iki ayda bir merkezi olarak PTT şubeleri aracılığıyla yapılmaktadır (SYGM 2014). Bunun yanında şartlı eğitim yardımlarının dışında verilen okul kıyafeti, kırtasiye malzemesi, çanta ve ayakkabı gibi eğitim yardımlarının ise kısmen yeterli olduğu faydalanıcılar tarafından ifade edilmiştir.

\section{Eğitim İhtiyaçlarını Karşılayabilme ile İlgili Bulgular}

Tablo 10. Katılımcıların Eğitim İhtiyaçları Hakkında Görüşleri

\begin{tabular}{lll}
\hline $\begin{array}{l}\text { Eğitim } \\
\text { ihtiyaçlarını } \\
\text { kendiniz } \\
\text { karşılayabilir } \\
\text { miydiniz? }\end{array}$ & $\boldsymbol{f}$ & $\%$ \\
\hline Evet & 1 & \\
Hayır & 85 & 1 \\
Kısmen & 14 & 85 \\
\hline Toplam & 100 & 14 \\
\hline
\end{tabular}

Eğitim ihtiyaçlarını kendiniz karşılayabilir miydiniz şeklindeki bir soruya ise 85 kişi hayır, 14 kısmen, sadece 1 kişi ise evet cevabı vermiştir

\section{Eğitim İhtiyaçlarının Aile Bütçesini Zorlaması ile İlgili Bulgular}

Tablo 11. Katılımcıların Eğitim Harcamaları Hakkında Görüşleri

\begin{tabular}{lll}
\hline $\begin{array}{l}\text { Ĕ̆itim } \\
\text { harcamaları } \\
\text { aile } \\
\text { bütçesini } \\
\text { zorluyor } \\
\text { mu? }\end{array}$ & $\boldsymbol{f}$ & $\%$ \\
\hline Evet & 98 & \\
Hayır & 0 & 98 \\
Kısmen & 2 & 0 \\
\hline Toplam & 100 & 2 \\
\hline
\end{tabular}

Ankete katılmayı kabul eden 100 katılımcıdan 98'i eğitim harcamalarının zaten zayıf olan aile bütçesini çok zorladığını 2 kişi ise kısmen zorladığını söylemiştir. Temel gıda ihtiyaçlarını karşılamakta zorlanan ailelerin çocuklarının eğitim ihtiyaçlarını karşılamakta ciddi güçlükler yaşadıkları görülmüştür. Ailelerin bir bölümü bu yardımlar olmasaydı çocuğumu okuldan almak zorunda kalacaktım şeklinde beyanda bulunmuştur. 
Eğitim Yardımlarının Amacına Uygun Kullanılıp Kullanılmadığı ile İlgili Bulgular

Tablo 12. Katılımcıların Eğitim Yardımları Hakkında Görüşleri

\begin{tabular}{|c|c|c|}
\hline $\begin{array}{l}\text { Eğitim } \\
\text { yardımları } \\
\text { amacina } \\
\text { uygun } \\
\text { kullanılıyor } \\
\text { mu? }\end{array}$ & $f$ & $\%$ \\
\hline Evet & 57 & 57 \\
\hline Hayır & 7 & 7 \\
\hline Kismen & 36 & 36 \\
\hline Toplam & 100 & 100 \\
\hline
\end{tabular}

Anket uygulanan 100 kişiden 57'si eğitim yardımlarını amacına uygun şekilde kullandığını, 7 kişi amacına uygun kullanmadığını ve 36 kişi ise kısmen uygun kullandığını belirtmiş̧ir. Eğitim yardımlarının nakdi olması yardımlarının amacına uygun kullanılmama riskini de beraberinde getirmektedir. Çünkü yardım para şeklinde olduğundan ve zaten ailelerin geçim güçlüğü yaşadığından, yardım o günkü acil ihtiyaca göre harcanmaktadır. Eğitim yardımlarını amacına uygun kullanmadığını söyleyen fayda sahipleri, harcayabilecekleri başka paraları bulunmadığından öğrencilerin ihtiyaçlarını ertelediklerini ve o an acil olan ihtiyaçları için eğitim yardımı paralarını kullandıklarını bildirmişlerdir. Kısmen amacına uygun kullandıklarını söyleyenler de günün ihtiyacına göre bu yardımları kullandıklarını söylemişlerdir. Bu açıklamalar da bize nakdi olarak yapılan yardımların yarıya yakın kısmının amacı dışında kullanıldığını göstermektedir. Yardımların ayni olarak ve bütün ihtiyaçları kapsayacak şekilde yapılması yardımların amaca hizmet edeceğinin göstermektedir.

Eğitim Döneminde Yapılan Eğitim Yardımlarının Fayda Sahiplerine Güven Verip Vermediği İle İlgili Bulgular

Tablo 13. Katılımcıların Eğitim Yardımları Hakkında Görüşleri

\begin{tabular}{|c|c|c|}
\hline $\begin{array}{l}\text { Eğitim } \\
\text { döneminde } \\
\text { böyle bir } \\
\text { yardımın } \\
\text { olması size } \\
\text { güven } \\
\text { veriyor } \\
\text { mu? }\end{array}$ & $f$ & $\%$ \\
\hline Evet & 99 & 99 \\
\hline Hayır & 1 & 1 \\
\hline Kismen & - & - \\
\hline
\end{tabular}




\begin{tabular}{lll}
\hline Toplam 100 & 100 \\
\hline
\end{tabular}

Eğitim dönemlerinde bu tür yardımların yapılması ailelere $\% 99$ oranında güven vermektedir. Eğitim dönemi başında öğrencilerin eğitim ihtiyaçlarının sosyal yardımlaşma vakfı tarafından karşılanması ailelerin okul açılınca çocuğumun ihtiyaçlarını nasıl karşılarım endişesini gidermeye yardımcı olduğu görülmüştür. Fayda sahiplerinin büyük bölümünün ailenin gıda ihtiyaçlarını bile karşılamakta zorlandığı düşünüldüğünde eğitim yardımlarının bu aileler için çok önemli ve hayati olduğu düşünülmektedir

Görüşülen fayda sahiplerinin tamamı bu tür yardımların devlete olan güveni artırdığını belirtmişlerdir. Bu tür yardımlar fayda sahiplerinin devletin şefkatli elinin her zaman yanında olduğunu hissetmelerine yardımcı olmaktadır.

\section{Eğitim Yardımlarının Öğrenci Devamsızlıklarına Etkilerine İlişkin Bulgular}

Tablo 14. Katılımcıların Eğitim Yardımlarının Öğrenci Devamsızlığına Etkileri Hakkında Görüşleri

\begin{tabular}{lll}
\hline $\begin{array}{l}\text { Eğitim } \\
\text { yardımları } \\
\text { çocuğun }\end{array}$ & & \\
$\begin{array}{l}\text { okula } \\
\text { devam } \\
\text { durumunu } \\
\text { etkiliyor } \\
\text { mu? }\end{array}$ & $\boldsymbol{f}$ & $\%$ \\
\hline Evet & 79 & \\
Hayır & 19 & 79 \\
Kısmen & 2 & 19 \\
\hline Toplam & 100 & 2 \\
\hline
\end{tabular}

Eğitim yardımlarından faydalanan aileler eğitim yardımlarını öğrencilerin okula devam durumunu etkilediğini söylemişlerdir. Görüşülen 100 kişiden $79^{\prime} \mathrm{u}$ yardımların öğrencilerin okula devam durumunu etkilediği, 19'u etkilemediğini, 2 kişi ise kısmen etkilediğini belirtmişlerdir. Yardımların okula devam durumunu etkilediğini söyleyen kişiler öğrencilerin ihtiyaçlarının karşılayamadığımızda çocuklar eski olan kıyafet, ayakkabı, çanta ve kırtasiye malzemeleri tam olmadığında okula gitmek istemediklerini söylemişlerdir. Öğrenciler arkadaşlarının yanında küçük düşebileceklerini düşündüklerinden dolayı okula gitmek istemedikleri anlaşılmıştır. Öğrencilerin bütün ihtiyaçlarının tamamlanması bu tür bahanelere sığınmalarını engellemeye yardımcı olacaktır. 
Katılımcıların Eğitim Yardımlarından Faydalanabilme Şartları Hakkındaki Bilgileri ile İlgili Bulgular

Tablo 15. Katılımcıların Eğitim Yardımlarından Faydalanabilme Şartları Hakkında Görüşleri

\begin{tabular}{lll}
\hline $\begin{array}{l}\text { Çocuğunuz } \\
\text { okula devam } \\
\text { etmediğinde }\end{array}$ & & \\
$\begin{array}{l}\text { yardım } \\
\text { alamayacağınızı } \\
\text { biliyor } \\
\text { musunuz? }\end{array}$ & $\boldsymbol{f}$ & $\%$ \\
\hline $\begin{array}{l}\text { Evet } \\
\text { Hayır }\end{array}$ & 87 & \\
\hline Toplam & 13 & 87 \\
\hline
\end{tabular}

Fayda sahiplerinin \%87'si çocuğun okula devam etmediği durumlarda yardımların kesileceğini biliyor. Ancak \%13'ünün yardımların devam etmesinin öğrencilerin okula devam durumuna bağlı olduğundan habersiz olduğu anlaşılmıştır. Bunu en büyük sebebi ise yardım sahiplerinin imzaladıkları ŞEY sözleşmesini okumadıklarını, okuma yazma bilmeyenlerin okuyamadıklarından veya sözleşmeyi çocuklarına okutmadığından kaynaklandığı düşünülmektedir. Fayda sahiplerinin tamamına yakının bu konuda bilinçli olduğu ve öğrencisini takip ettiği görülmektedir. Burada Şartlı Eğitim Yardımlarının şartlı olması ve izleme ve değerlendirme açısından da denetlenebilir olmasının yardımın etkinliğini artırdığı düşünülebilir.

\section{Eğitim Yardımlarının Öğrencilerin Okula devam İsteklerine İlişkin Bulgular}

Tablo 16. Katılımcıların Eğitim Yardımlarının Okula Devamı Sağlaması Hakkında Görüşleri

\begin{tabular}{lll}
\hline $\begin{array}{l}\text { Çocuğun } \\
\text { okula gitmek } \\
\text { istemediği }\end{array}$ & & \\
$\begin{array}{l}\text { zamanlarda } \\
\text { eğitim } \\
\text { yardımlarının } \\
\text { onu ikna } \\
\text { edilmesinde } \\
\text { payı var mı? }\end{array}$ & $\boldsymbol{f}$ \\
\hline Evet & 15 & \\
Hayır & 84 & \\
Kismen & 1 & 15 \\
\hline Toplam & 100 & 84 \\
\hline
\end{tabular}

Çocuğunuz okula gitmek istemediği zamanlarda eğitim yardımları çocuğunuzu okula gitmeye ikna etmenize yardımcı oluyor mu şeklindeki soruya 100 fayda sahibinden 15 'i evet şeklinde 
cevaplandırmıştır. 84 kişi ise böyle bir sorunlarının olmadığını, 1 kişi ise kısmen ikna etmeye yardımc1 olduğunu belirtmiştir.

\section{Eğitim Yardımlarının Öğrencilerin Başarılarına Etkisi Hakkında Veli Görüşlerine İlişkin Bulgular}

Tablo 17. Katılımcıların Eğitim Yardımlarının Çocuğun Başarısına Etkileri Hakkında Görüşleri

\begin{tabular}{lll}
\hline $\begin{array}{l}\text { Eğitim } \\
\text { yardımlarının } \\
\text { artırılması } \\
\begin{array}{l}\text { cocuğunuzun } \\
\text { başarısını } \\
\text { etkiler mi? }\end{array}\end{array}$ & $\boldsymbol{f}$ & $\%$ \\
\hline Evet & 93 & \\
Hayır & 5 & 93 \\
Kısmen & 2 & 5 \\
\hline Toplam & 100 & 2 \\
\hline
\end{tabular}

Eğitim yardımlarının artırılması çocuğunuzun başarısını etkiler mi şeklindeki soruya 100 kişiden 93'ü evet, 5 kişi hayır, 2 kişi de kısmen cevabı vermiştir. Velilerle uygulanan anketler sonucunda eğitim yardımlarının ciddi biçimde artırılması görüşü öne çıkmıştır. Özellikle nakdi olarak verilen şartlı eğitim yardımlarının öğrencilerin harçlıklarını bile karşılamaktan uzak olduğu beyan edilmiştir. Velilerden bazıları maddi olanaklarının zayıf olmasından dolayı öğrencilerinin temel bazı ihtiyaçlarını karşılayamadıklarını, öğrencilerinin diğer öğrencilerin yanında rencide olduklarını ve ders çalışma ve okuma şevklerinin kırıldığını söylemişlerdir. Bazı veliler de öğrencilerine daha iyi imkânlar sunulması halinde öğrencilerinin başarısının artacağı görüşündeler. Hayır, cevabı veren veliler çocuklarının kapasitesinin bu kadar olduğunu düşünüyorlar ve yardımlar veya maddi imkânlarla çocuklarının başarısının artmayacağı görüşündeler.

Hangi farklı eğitim yardımları çocuğunuzun başarısını etkiler sorusuna 100 veliden 81 tanesi kaynak kitaplar şeklinde cevap vermiştir. Veliler özellikle okullardan sürekli kaynak kitaplar istendiğini fakat maddi imkânsızlıklardan dolayı alamadıklarını beyan etmişlerdir. Bunun sonucu olarak da öğrencilerinin diğer öğrencilerden geri kaldığını ve başarılı olmakta zorlandığını belirtmişlerdir. 81 veliden 55 tanesi kaynak kitaplarla birlikte aynı zamanda bilgisayar olmasının öğrencilerinin başarısını artıracağını düşünmektedir. Veliler öğrencilerinin ödevlerinin birçoğunun internet ortamında yapılması gerektiğinden çoğu zaman öğrencilerinin ödevlerini imkânsızlıklardan dolayı yapamadıklarını bildirmişlerdir. Veliler, internet için öğrencileri dışarı göndermenin de riskleri olduğunu düşünüyorlar. 24 veli ise özel ders ve kursların öğrencilerinin başarısını artırabileceğini düşünüyorlar. Maddi durumu iyi olan ailelerin öğrencilerinin özel ders ve kurslarla arayı açtığı düşünülüyor ve kendi öğrencileri için de ücretsiz kurs veya etüt imkânının sağlanmasının eğitimde kısmen firsat eşitliğini sağlayacağını ve kendi öğrencilerinin de başarılı olabileceği düşünülüyor. 


\section{Eğitim Yardımlarının İçeriğine İlişkin Bulgular}

Tablo 18. Katılımcıların Eğitim Yardımlarının Mahiyeti Hakkında Görüşleri

\begin{tabular}{lll}
\hline $\begin{array}{l}\text { Eğitim } \\
\text { yardımlarının } \\
\text { nasıl }\end{array}$ & $\boldsymbol{f}$ & \\
$\begin{array}{l}\text { yapılmasını } \\
\text { istersiniz? }\end{array}$ & & $\%$ \\
\hline Ayni & 30 & 30 \\
Nakdi & 64 & 64 \\
Her ikisi de & 6 & 6 \\
\hline Toplam & 100 & 100 \\
\hline
\end{tabular}

Uygulanan anketlerde yardımların nasıl yapılmasını istersiniz şeklindeki bir soruya 64 kişi nakdi yani para olarak verilmesini talep etmiştir. Nakdi olarak talep edilmesine gerekçe olarak da öğrencilerin ihtiyaçlarına göre harcamak istediklerini ifade etmişlerdir. Nakdi yardımların her zaman amacı dışında kullanılma riski bulunmaktadır. Ancak diğer taraftan harcama serbestîsi getirdiğinden ihtiyaç olmayan malzemelerin tekrar alınarak gereksiz kaynak harcamasını önlemektedir. Bazı fayda sahipleri ise ayni olarak temin edilen ürünlerin özellikle ortaokul ve lise öğrencileri tarafından beğenilmediğini dile getirmişlerdir. Yardımların nakdi olarak verilmesi halinde ise öğrencilerin istediği ürünleri ve ihtiyaç olan ürünleri alma imkânı sağladı̆̆ından kaynak israfının da önüne geçildiği dile getirilmiştir. Anket uygulanan velilerden 30 kişi ise yardımların ayni olarak yapılmasını talep etmektedir. Aynı olarak talep eden veliler ise nakdi verilen yardımları öğrencilerine harcamadıklarını ve diğer ihtiyaçları için harcadıklarını beyan etmişlerdir. Bazı veliler ise ayni olarak verilen yardımların öğrencilerin ihtiyaçlarını karşıladığını ve nakdi olarak verilmesi halinde ise bu ihtiyaçların birçoğunu karşılayamayacaklarını bildirmişlerdir. Bir grup veli ise, yardımların ayni olarak verilmesinin, yardımların hem ekonomik hem de amacına uygun olarak kullanıldığını ve nakdi verildiği zaman öğrencilerinin ihtiyaçlarını alamadıklarını, öğrencilerinin yine eski kıyafet ve eski ayakkabıları ile okula gitmek zorunda kaldıklarını söylemişlerdir. Çünkü eğitim için verilen parayı diğer ihtiyaçları için kullandıklarını belirtmişlerdir. Velilerden 6 kişi ise hem ayni hem nakdi yardım yapılmasını talep etmişlerdir. Buna gerekçe olarak da o ihtiyaç için verilen nakdi yardımın yetersiz olduğu, ancak özellikle kırtasiye ihtiyaçlarının okuldan okula farklılık gösterdiğinden bu ihtiyaçlar için nakdi yardım verilmesinin uygun olacağını ifade etmişlerdir. 

Eğitim Yardımlarının Kadın Katılımcıların Ailedeki Sosyal Konumuna Etkisine İlişkin
Bulgular

Tablo 19. Kadın Katılımcıların Eğitim Yardımlarının Aile İçerisindeki Konumlarına Etkisi

\begin{tabular}{lll}
\hline $\begin{array}{l}\text { Aldığınız } \\
\text { eğitim }\end{array}$ & & \\
$\begin{array}{l}\text { yardımları } \\
\text { ailenizdeki }\end{array}$ & $\boldsymbol{f}$ & $\%$ \\
$\begin{array}{l}\text { sosyal } \\
\text { konumunuzu } \\
\text { etkiliyor } \\
\text { mu? }\end{array}$ & & \\
\hline $\begin{array}{l}\text { Evet } \\
\text { Hayır }\end{array}$ & 72 & 92 \\
\hline Toplam & 78 & 8 \\
\hline
\end{tabular}

Özellikle evli ve eşiyle ayni hanede yaşayan bayanlara sorulan eğitim yardımlarının annelere verilmesi sizin ailedeki sosyal konumunuzu etkiliyor mu şeklindeki soruya ise 78 anneden 72 si evet sadece 6 kişi hayır yanıtını vermiştir. Burada bazı anneler eşlerinin daha önceleri kendilerine davranışlarının farklı olduğunu, eğitim yardımlarını almaya başladıktan sonra ise artık kendilerinin de haneye ekonomik manada katkı sağlayan biri olarak görülmeye başlandığını söylemiş̧lerdir. Hatta bir anne, yardım almadan önce eşinin sürekli kendisine kötü davrandığını ve bağırdığını, yardım almaya başladıktan sonra ise artık eşinin kendisine çok iyi davrandığını ve bağırmadığını beyan etmiştir. Hayır, cevabı veren annelerin 4 kişi çalıştı̆̆ını, 2 kişi ise ailelerinde böyle bir konunun hiç gündeme gelmediğini beyan etmiştir. Yapılan anket uygulamaları bize yardımların anneler vasitasıyla verilmesinin hem annenin ailedeki sosyal konumunu etkilediği, hem de yardımların amacına uygun kullanma noktasında annelerin daha duyarlı olduklarını göstermiştir.

Muratpaşa SYDV'nin yaptığı eğitim yardımlarının okul terklerinin azalmasına katkı sağladığı, eğitim yardımının özellikle annelere verilmesinin annelerin özgüvenini artırdığı görülmüştür. Annelerin bir bölümünün okuma-yazma bilmemesine rağmen yardım müracaatında bulunmak zorunda kalması hem annenin sosyalleşmesini hem de okuma-yazmayı zorunlu bir ihtiyaç olarak görmelerini sağladığından özellikle genç ve orta yaştaki annelerin okumayazmayı öğrenme isteklerinin arttığı görülmüştür. Burada vakıf görevlilerinin de vatandaşları bu yönde bilgilendirmeleri ve cesaretlendirmelerinin annelerin okuma-yazma öğrenme isteğinde etkili olduğu söylenebilir. Zorunlu eğitimin 12 yıla çıarılmasıyla toplumun en alt gelir grubunda bulunan öğrencilerin yoksulluk nedeniyle eğitimlerinin yarım kalması veya eğitimlerine devam edememe riski bulunmaktadır. Eğitimin 12 yıla çıkmasıyla liseye devam eden öğrencilerin ihtiyaçları da artmaktadır. Özellikle okulların öğrencilerin evlerine uzak olması, ulaşım, öğle yemeği gibi ek harcamaları da beraberinde getirmektedir. Muratpaşa İlçesi'nde verilen eğitim yardımlarının yoksul kesimde liseye devam eden öğrenci sayısında önemli artışlar sağladığı görülmüştür. Eğitim yardımı başvuru sayısında önemli bir artış olmamasına rağmen 2014-2015 eğitim öğretim yılında eğitim yardımı alan öğrenci sayısı 76 iken 2015-2016 eğitim öğretim yılında eğitim yardımı alan öğrenci sayısı 174'dür (Muratpaşa SYDV 2014-2015 \& 2015-2016). Bunun en önemli sebebinin öğrenci taşıma yardımlarının yapılması ve yılda bir defa olmak 
üzere AB projesi kapsamında sadece lise öğrencileri için yılda bir defa nakdi olarak ödenen eğitim desteğinin olduğu düşünülmektedir. Fakirliğin gelecek nesillere miras olarak bırakılması sorunların kartopu gibi giderek büyümesine neden olmaktadır. Özellikle risk altında bulunan yetim, öksüz ve kimsesiz çocuklar, parçalanmış ailelerin çocukları ile fakir ailelerin çocuklarının eğitimlerinin sağlanması Türkiye'nin orta gelir tuzağından çıkmasına katk1 sağlayacağı ve gelişmiş ülke statüsüne yükselmesine büyük etkiler yapacağı düşünülmektedir.

\section{Sonuç ve Öneriler}

Antalya'nın yaklaşı 500.000 (TÜIKK 2015) nüfusu olan Muratpaşa İlçesi'nde 2015-2016 eğitim öğretim yılı için 622 aile ve 1624 öğrenci eğitim yardımlarından faydalanmaktadır (Muratpaşa SYDV 2016). Eğitim yardımlarından faydalanan 100 veliye anket uygulanmıştır. Anket uygulanan bireyler rastgele seçilmiştir Düzenlenen 27 soruluk anket formu ile fayda sahiplerine uygulanan anketlerden elde edilen sonuçlar değerlendirilmiştir. Tarama yöntemiyle uygulanan ankete katılanların \%88'i bayanlardan \%12'si erkeklerden oluşmaktadır. Burada bayanlarla anket uygulamasının en önemli sebebi eğitim yardımı faydalanıcılarının tamamına yakın bölümünün bayanlardan oluşmasıdır. Ayrıca şartlı eğitim yardımları (ŞEY) yardımları programı yönetmeliği gereği sadece anneye yapılabilmektedir (SYGM 2014). Katılımcıların eğitim durumlarına bakıldığında 23 kişinin okur-yazar olmaması, 11 kişinin ilkokul mezunu olmamasına rağmen okuma yazma bilmesi, 56 kişinin ilköğretim mezunu olması, 9 kişinin lise mezunu ve 1 kişinin üniversite mezunu olması eğitim yardımları müracaatçılarının eğitim düzeyinin oldukça düşük olduğunu göstermektedir. Muratpaşa İlçesi'nde eğitim düzeyi arttıkça eğitim yardımına olan ihtiyaç azalmaktadır. Toplumun en alt gelir grubundaki ailelerin eğitim düzeyinin düşük olması tesadüf değildir. Eğitim düzeyinin düşük olması vasıfsız işgücü sayısını da artırmaktadır. Bu çalışma ile eğitim düzeyi ile yoksulluk arasındaki bağlantı bir defa daha teyit edilmiştir.

Ankete katılan gönüllülerin medeni durumlarına bakıldığında ise \%76'sının evli, \%19'unun boşanmış, \%2'sinin dul, \%3'nün ise eşinin cezaevinde olduğu görülmüştür. Bu durum eğitim yardımı faydalanıcılarının yaklaşık dörtte birinin Türkiye'de risk grubunda değerlendirilen ailelerden oluştuğunu göstermektedir. Ankete katılan ailelerin \%56'sının iş için, \%5'inin zorunlu göç, \%28'inin ailesinin buralı olması ve \%11'inin ise diğer sebeplerden dolayı Muratpaşa İlçesi'nde yaşadıkları görülmüştür. Burada fayda sahibi vatandaşların yarıdan fazla bölümünün iş bulma umuduyla Muratpaşa'ya geldikleri görülmektedir. Bunun en önemli sebebini Muratpaşa İlçesi'nin çok hızlı büyüyen ve gelişen bir ilçe olmasıyla açıklanabilir. Ailelerinin daha önce burada yaşaması sebebiyle burada yaşayan fayda sahiplerinin dörtte birden az olması ise artık çevre edinen ailelerin yardıma ihtiyaç duyma oranının nispeten azaldığ 1 şeklinde değerlendirilebilir. Araştırmada ailelerin \%60'1nda 5 kişi ve üzeri birey bulunduğu, \%23'ünde 4 kişi, \%11'inde 3 kişi ve \%6'sında ise 2 kişi bulunduğu ifade edilmiştir. Görüşülen ailelerde hanede yaşayan kişi sayısı arttıkça eğitim yardımına ihtiyacın da arttığı, hane nüfusu azaldıkça yardıma gereksinimin de azaldığı düşünülebilir. Ankete katılan velilerden \%26'sının 1 öğrencisi, \%43'ünün 2 öğrencisi, \%19'unun 3 öğrencisi, \%11'inin 4 öğrencisi ve \%1'inin 5 öğrencisi bulunmaktadır. Değerlendirmede ortalama hane başına 3 öğrencinin bulunduğu görülmüştür. Eğitim yardımlarından faydalanan hanelerin \%11'inde çalışan kimse bulunmamaktadır. Bu haneler sosyal yardımlar, nafaka veya ailelerinin destekleriyle geçinmektedirler. Ailelerin \%78'inde 1 kişi çalışmaktadır. Bu durumu eğitim yardımından faydalanan ailelerin büyük bölümünün çekirdek aile ve eşlerin ev hanımı olduğu şeklinde değerlendirebiliriz. Görüşülen katılımcıların \%10'unda hande 2 kişi çalışmaktadır. Sadece \%1'inde 3 kişi çalışmaktadır. Ancak çalışanların gelirleri düzenli ve sabit olmadığı için ailelerin yoksulluğunu azaltmada yetersiz kalmaktadır. Hanede çalışanların büyük bir bölümü gündelik işlerde veya mevsimlik olarak 
çalışmaktadır. Muratpaşa ilçesinde çalışanların büyük bir bölümünün turizm, tarım ve inşaat işleri gibi mevsimsel işlerde çalışmaları mevsimsel ya da dönemsel yoksulluğu da beraberinde getirmektedir. Bu haneler çalışma mevsiminde yardıma ihtiyaç duymamakta fakat sezonun bitmesiyle birlikte geçici de olsa yardıma ihtiyaç duymaktadırlar.

Ayrıca katılımcıların \%24'ü diğer kurumlardan da yardım almaktadır, \%76'sı ise başka hiçbir kurumdan yardım almamaktadır. Sosyal Yardımlaşma ve Dayanışma Vakıfları dışında Belediyeler, Vakıflar Bölge Müdürlüğü, Aile ve Sosyal Politikalar İl Müdürlüğü ve diğer özel dernek ve vakıflar da sosyal yardım yapabilmektedirler. Bu bağlamda diğer kurumların da sosyal yardım yapması mükerrer yardım yapma olasılığını gündeme getirse de durumun böyle olmadığı, kurumları sistemlerinde diğer kurumların yardımlarını görmekte ve yardım miktarlarını ona göre belirlemekte, yani veri paylaşımı ile mükerrer yardımların önüne geçebilmektedirler. Ankete katılan fayda sahiplerinin \%4'ünde sigara dışında kötü alışkanlıklar bulunduğu, \%96'sında ise sigara dışında kötü alışkanlıklar bulunmadığ 1 beyan edilmiştir. Hanede sigara ve diğer kötü alışkanlıkların bulunması nakdi olarak verilen eğitim yardımlarının kötü alışkanlıklar için de kullanılabilme riskini de beraberinde getirmektedir. Bu durumun göz önüne alınarak yardımların hane analizine göre ayni olarak da yapılması değerlendirilebilecek bir alternatiftir.

Katılımcıların \%61'i eğitim yardımlarını yetersiz bulmaktadır. \%21'i eğitim yardımlarının kısmen yeterli olduğunu ve sadece \%18'i ise eğitim yardımlarının yeterli olduğunu düşünmektedir. Eğitim yardımlarını yeterli gören ailelerin ya çok kalabalık olmadığı ya da yardıma kısmen ihtiyaç duyduğu düşünülebilir. Aileler özellikle şartlı eğitim yardımlarında, öğrenci başına iki ayda bir verilen nakdi desteğin, öğrencilerin ihtiyaçlarını karşılamaktan çok uzak olduğunu düşünmektedirler. Fayda sahiplerinin \%86'sı yardımlar olmasaydı çocuklarını okula göndermekte çok ciddi zorluklar yaşayacaklarını ifade etmektedirler. Eğitim için verilen yardımların yarıya yakın bölümünün amacına uygun kullanılmadığı faydalanıcılar tarafından ifade edilmiştir. $\mathrm{Bu}$ durum fayda sahiplerinin diğer temel ihtiyaçlarını karşılamakta güçlük çektikleri ve \%77'sinin kötü alışkanlıklarının da bulunduğu şeklinde açıklanabilir. Eğitim yardımlarının eğitim dönemi başlangıçlarında yoksul haneler için adeta bir can simidi vazifesi gördüğü faydalanıcılar tarafından beyan edilmiştir. Katılımcıların \%99'u eğitim döneminde böyle bir yardımın olmasının kendilerine güven verdiğini söylemişlerdir. Eğitim dönemi başlangıcında verilen eğitim yardımları, fayda sahiplerinin çocuğumun eğitim ihtiyaçlarını nasıl karşılayabilirim endişesini ortadan kaldırdığı değerlendirilmektedir. Eğitim yardımlarının ailelerin devlete güvenini \%100 oranında $\operatorname{artırdığ1~ve~aidiyet~duygusunu~perçinlediği~fayda~sahipleri~tarafından~belirtilmiştir.~Veliler~eği-~}$ tim yardımlarının öğrencilerin okula devam durumunu \%81'lik bir oranla etkilediğini beyan etmiş̧lerdir. Burada verilen yardımlarla, öğrencilerin ihtiyaçlarının karşılanması diğer öğrencilerin yanında küçük düşme endişesiyle okula gitmek istememe durumunu ortadan kaldırdığı, bu durumun da öğrencilerin okula devam durumuna olumlu yönde katkı sağladığı ankete katılanlar tarafından beyan edilmiştir. Öğrencilerin okula devam etmediği durumda yardımların kesileceğinden bilgisi olan velilerin \%87 gibi yüksek bir oranda olması fayda sahiplerinin eğitim yardımları konusunda bilinçli olduklarını göstermektedir. Ankete katılan velilerin \%93'ü eğitim yardımlarının arttırılmasının çocukların başarısını olumlu yönde etkileyeceği yönünde görüş beyan etmişlerdir. Öğrenci velilerinden \%64'ü yardımların nakdi olarak yapılmasını, \%30’u ayni olarak yapılmasını, \%6's1 ise hem ayni hem nakdi olarak yapılmasını istediklerini beyan etmişlerdir. Nakdi olmasını tercih edenler nakdi yardımların harcama kolaylığ 1 ve istedikleri ürünleri alabilme imkânı sağladığı için tercih ettiklerini ifade etmişlerdir. Ayni olarak tercih edenler ise samimi bir itirafla paranın ellerine verilmesi halinde öğrencilerin ihtiyaçlarının alınmadığını ve bu kaynakların başka ihtiyaçlar için harcandığını bildirmişlerdir. Nakdi yardımların her tür ihtiyaç için harcanabilmesi amacına uygun kullanılmama riskini doğurmaktadır. Bu riski 
ortadan kaldırmak için her aile için ailenin durumuna uygun yardım modelinin belirlenmesi, bu sorunun çözümüne katkılar sağlayabileceği düşünülmektedir.

Eğitim yardımlarının tamamına yakınının annelere verilmesinin, annelerin \%92'sinin ailedeki sosyal konumuna olumlu yönde katkı sağladığı katılımcılar tarafından ifade edilmiștir. Özellikle ev hanımı anneler aldığı yardımlar sayesinde, eşleri tarafından aile bütçesine katkı sağlayan biri olarak görüldüklerini belirtmişlerdir. Uygulanan anketlerde eğitim yardımlarının annelere verilmesi, annelerin özgüvenlerini artırdığı ve eşlerinin davranışlarına olumlu yönde katkılar sağladığı ifade edilmiştir.

Özellikle son iki yılda $A B$ hibe programları olarak uygulanan ve yılda bir defa olmak üzere verilen yaklaşık 230 Lira tutarındaki desteğin lise öğrencilerinin örgün eğitime devam etmelerinde önemli artışlar sağladığı düşünülmektedir. Burada Muratpaşa SYDV özelinde yapılan ve başka SYDV'ler tarafından da uygulanan öğrenci taşıma yardımlarının özellikle lise öğrencilerinin örgün eğitime devamı üzerinde olumlu etkileri olduğu görülmüştür. Velilerin de öğrenci taşıma yardımlarını liseye devam eden öğrenciler için bir teşvik yardımı olarak görmeye başladıkları anlaşılmıştır.

Eğitim yardımları öğrenci başına ele alındığında miktarların yetersiz olduğu, sadece devletin yaptığı sosyal yardımlarla öğrencilerin ihtiyaçlarının tamamının karşılanmasının mümkün olmadığı görülmektedir. Özellikle liseye devam eden öğrencilerin eğitim ihtiyaçlarının karşılanmasının lisede okul terklerinin önlenmesinde, açık liseye geçişlerin azaltılmasında etkili olabileceği düşünülmektedir.

Eğitim yardımlarının her hanenin yoksulluk derecesine göre belirlenmesi, her aile için farklı yardım programları uygulanması eğitim yardımlarının etkisini artıracaktır. Devletin yanında kamu yararına faaliyet gösteren sivil toplum örgütleriyle müşterek çalışma yapılması ve projenin halk tarafından da sahiplenilmesini sağlamak hem hizmetlerin sürekliliğini artıracak hem de toplumun birbiriyle kaynaşmasına büyük katkılar sunacaktır.

Eğitim yardımlarının verimliliğinin sağlanabilmesi için okul, öğrenci ve aile birlikte değerlendirilmelidir. Okula devam ve öğrenci akademik başarısı odaklı eğitim yardımları çalışmaların içerisine, velilerin sosyoekonomik gelişimleri de dahil edilebilir. Bu doğrultuda Türkiye İş Kurumu tarafindan sosyal yardım alan bireylere işe yerleştirmede öncelik verilmesinin önü açılabilir. Ailedeki çalışabilecek bireylerin Türkiye İş Kurumu ile müşterek çalışmayla işe yerleştirilmesi sağlanabilir. Yardımların iş arama ile bağlantısının kurulması ve talebine rağmen Türkiye İş Kurumu tarafından işe yerleştirilememiş olan kişilere yardımlardan faydalanmada öncelik verilmesi sağlanabilir.

Mesleği olmayan bireylerin meslek edindirme kurslarına yönlendirilmesi, mesleği olan bireylere işyeri açma olanağı sağlanması, çalışacak kimsesi bulunmayan hanelere yardım miktarı artırılması düşünülebilir. 


\section{KAYNAKÇA}

Aile ve Sosyal Politikalar Bakanlığı (2012). Türkiye'de Uygulanan Şartlı Nakit Transferi Programının Fayda Sahipleri Üzerindeki Etkisinin Nitel ve Nicel Olarak Ölçülmesi Projesi Final Raporu. Ankara 2012.

Aile ve Sosyal Politikalar Bakanlığı (2014). Sosyal Yardımlar Genel Müdürlüğ̈̈ 2014 Yılı ŞEY Düzenlemesi. (17.10.2014 tarih ve 2014/6 sayll Fon Kurulu Kararl).

Aile ve Sosyal Politikalar Bakanlığ (2015). Aile ve Sosyal Politikalar Bakanlı̆̆ 2015 Yllı Faaliyet Raporu (2015) 125-126.

Atkinson A. B. \& Marlier E. (2010). Income and Living Conditions in Europe. Luxembourg 2010.

Başbakanlık Sosyal Yardımlaşma ve Dayanışma Genel Müdürlüğü. (2005). Başbakanlık Sosyal Yardımlaşma ve Dayanışma Genel Müdürlüğü Broşürü. Ankara 2005.

Esenyel C. (2009). Türkiye'de ve Dünyada ŞNT Uygulamaları. Uzmanlık Tezi. SYDGM, Ankara 2009.

Karasar N. (2006). Bilimsel Araştırma Yöntemi. Ankara 2006.

Muratpaşa Sosyal Yardımlaşma ve Dayanışma Vakfi. (2015). 2014-2015 Faaliyet Raporu. Antalya 2015.

Muratpaşa Sosyal Yardımlaşma ve Dayanışma Vakfi. (2016). 2015-2016 Faaliyet Raporu. Antalya 2016.

Rawlings L. B. \& Bénédicte de la B. (2006). "Examining Conditional Cash Transfer Programs: A Role for Increased Social Inclusion?”. The World Bank, Social Protection Discussion Paper. No: 0603. Washington 2006.

Sosyal Yardımlar Genel Müdürlüğü (2014). Şartl Eğitim Yardımları Mevzuat Değisşikliği (17.10.2014 Tarih ve 2014/6 Sayll Fon Kurulu Kararl).

Sosyal Yardımlar Genel Müdürlüğü. (2014). 2015-2016 Şartlı Eğitim Yardımı Programı (13.02.2014 Tarih ve 2014/1 Sayll Fon Kurulu Kararl).

Sosyal Yardımlaşma ve Dayanışma Genel Müdürlüğü. (2007). 2007 Faaliyet Raporu.

Sosyal Yardımlaşma ve Dayanışma Genel Müdürlügüu. (2009). 2003-2009 Faaliyet Raporu.

Türkiye İstatistik Kurumu. (2007). "2006-2013 Yılları Arasında Yoksulluk Çalışmaları İstatistikleri”. Kaynak: http://www.tuik.gov.tr/PreTablo.do?alt_id=1013

Türkiye İstatistik Kurumu. (2015). “Adrese Dayalı Nüfus Kayıt Sistemi Sonuçları”. Kaynak: http://www.tuik.gov.tr/PreTablo.do?alt_id=1047

UNDP. (2003). Human Development Report. New York 2003.

Yıldırım A. \& Şimşek H. (2011). Sosyal Bilimlerde Nitel Araştırma Yöntemleri. Ankara 2011. 